\title{
Diagnostic and Prognostic Potential of Circulating Long Non-Coding RNAs in Non Small Cell Lung Cancer
}

\author{
Wei Peng ${ }^{\mathrm{a}} \quad$ Jun Wang ${ }^{\mathrm{a}} \quad$ Bin Shan $^{\mathrm{b}} \quad$ Zhenzi Peng $^{\mathrm{a}} \quad$ Yeping Dong $^{\mathrm{a}} \quad$ Wenwen Shi $^{\mathrm{a}}$ \\ Dan He $^{d}$ Yuanda Cheng ${ }^{c}$ Wenyuan Zhao ${ }^{a}$ Chunfang Zhang ${ }^{c}$ Bin Lie \\ Chaojun Duan ${ }^{\mathrm{a}}$ \\ anstitute of Medical Sciences, Xiangya Hospital, Central South University, Changsha, China, ${ }^{b}$ College \\ of Medicine, Washington State University Spokane, Spokane, USA, 'Department of Thoracic Surgery, \\ Xiangya Hospital, Central South University, Changsha, ${ }^{d} H u n a n$ Cancer Hospital,the Affiliated Tumor \\ Hospital of Xiangya Medical College,Central South University, Changsha, 'Department of Oncology, \\ Xiangya Hospital, Central South University, Changsha, China
}

\section{Key Words}

Lung cancer $•$ Long non-coding RNAs $•$ Biomarker

\begin{abstract}
Lung cancer is the leading cause of cancer-related mortality worldwide. Approximately $80 \%$ of lung cancer cases are non-small cell lung carcinoma (NSCLC). However current diagnostic and therapeutic modalities against NSCLC are ineffective due to incomplete understanding of molecular pathogenesis of NSCLC. Emerging evidence shows that long non-coding RNAs (IncRNAs) can function as biomarkers for diagnosis and prognosis. LncRNAs can control transcription, translation, and protein function via diverse mechanisms although they lack the protein coding potential. LncRNAs have attracted intense investigations on their roles in cancer. Mounting evidence indicates that IncRNAs are promising biomarkers in diagnosis and prognosis for NSCLC, especially their presence in body fluids. Herein we will review recent advances in the research that explores the diagnostic and prognostic potentials of IncRNAs in NSCLC. We will also discuss emerging evidence that suggested IncRNAs as therapeutic targets in NSCLC.

(C) 2018 The Author(s)

Published by S. Karger AG, Basel
\end{abstract}

\section{Introduction}

Lung cancer is the most common cancer among men and women and leading cause of cancer related morbidity and mortality worldwide. Due to environmental pollution, it is estimated that more than 2.2 million people were newly diagnosed and approximately 1.5 million people died from this disease in 2017 [1]. Non-small cell lung carcinoma (NSCLC) accounts for $80 \%$ of total lung cancer cases and is divided into three histological types, 
namely lung adenocarcinoma, large cell carcinoma, and lung squamous cell carcinoma. Different histological types respond differently to chemotherapies [2-5]. A minor histological type is adenosquamous carcinoma that accounts for $0.6-2.3 \%$ of lung cancer and is often misdiagnosed as adenocarcinoma or squamous cell carcinoma due to its mixed clinical and pathological characteristics.

Lung adenocarcinoma is the most common histological type. There are many studies on targeted therapy of lung adenocarcinoma, such as tyrosine kinase inhibitors (TKIs) of the epidermal growth factor receptor (EGFR) [6]. The patients who are initially responsive to TKIs usually develop drug resistance in 8-12 months after initiation of their TKI target therapy [7]. Resistance to TKI target therapy has been under intense investigation.

\section{Current Diagnostic Method for Lung Cancer}

Pathological diagnosis is the gold standard in clinic setting. Chest radiograph has been used to screen for lung cancer for the past two decades, but its false negative rate is high [8]. Low dose spiral computed tomography(CT) was developed to increase sensitivity of screen for lung cancer [9]. A recent advance is fluorodeoxy glucose-positive emissiontomography (FDG-PET) scan that substantially increases specificity and sensitivity when compared to the previous methods [10-12]. Circulating tumor cells (CTCs) [13], tumor-educated platelets [14] and tumor-associated autoantibodies (TAAbs) [15] also emerge as promising methods for screening of NSCLC. LncRNAs have emerged as a new class of biomarkers for diagnosis and prognosis of NSCLC. Microarray and genomewide deep sequencing can reveal specific lncRNAs and their potential functions in NSCLC subtypes [16].

\section{Brief introduction of Long non-coding RNAs}

LncRNAs are a class of non-coding RNAs that are longer than 200 nucleotides in length and lack the protein coding potential [17]. Recently, Iyer et al. demonstrated that there are about 60000 ncRNAs in the human genome and more than $70 \%$ of these are lncRNAs [18]. About $80 \%$ of IncRNAs are not annotated. LncRNAs can regulate biological processes via diverse molecular mechanisms, such as decoys, scaffold, signal transducer, sponges for miRNAs, and a guide for chromatin modifiers $[19,20]$.

\section{Biological functions of IncRNAs}

A large number of IncRNAs regulate the expression protein-coding genes via in cis (affecting neighboring genes) or in trans (affecting distant genes on different chromosomes) mechanisms [21, 22] . Various lncRNAs have been reported to regulate individual genes and gene expression programs through epigenetic regulation or by altering the basal transcriptional machinery. Specifically, IncRNAs can (1) regulate the downstream genes' transcription; (2) regulate mRNA splicing patterns and produce different splice variants; (3) modulate protein's activity; (4) scaffolds for assembly of multiple component complexes; (5) regulate proteins' subcellular localization; (6) function as transcriptional precursors of small RNAs [23] . It is conceivable that aberrant expression of lncRNAs results in dysregulation of normal biological and pathological processes and thereby contributes to to the pathogenesis of disease [24]. Utilizing comparative mammalian genomics approach coupled with evolutionary analysis, Khachane and Harrison identified a small population of conserved IncRNAs in the evolution, and proposed that these lncRNAs could play an important role in tumorigenesis [25]. A large number of lncRNAs exhibit altered expression in cancer cells compared with healthy tissue of the same origin $[26,27]$. 


\section{Cellular Physiology Cell Physiol Biochem 2018;49:816-827 \begin{tabular}{c|c|c|c} 
DOI: 10.1159/000493043 & O 2018 The Author(s). Published by S. Karger AG, Basel \\
wwww.karger.com/cpb
\end{tabular} \\ Published online: 30 August,}

\section{LncRNA in lung cancer diagnosis and tumor types}

The diagnosis of lung cancer largely relies on tissue biopsy. However it has considerable limitations, such as small amount of tissue extracted and complication derived from necrotic tissues within tumors. Because of the tumor heterogeneity, adenocarcinoma and squamous cell carcinoma can exist in the same tumor. So, there is a possibility that an adenosquamous carcinoma is misdiagnosed as adenocarcinoma or squamous cell carcinoma [28-30]. Increasing number of lncRNAs are associated with lung adenocarcinoma (LUAD), lung squamous cell cancer (LSCC), etc [31]. LncRNAs bear the potential as a new category of biomarkers for diagnosis of NSCLC.

Using qRT-PCR, RNA-SEQ and the TCGA dataset, Tian and his colleges [32] aimed to generate a histopathology relevant lncRNAs for scanning of functional lncRNAs in 6 TNM I stage (stage I) LUAD. They found that the expression of LINC00963, NR2F2-AS1, LINC00515, LINC00162, LINC00312, MGC27382, LINC00472 and FENDRR were significantly dysregulated in LUAD tissues. CDKN2B-AS1 was significantly up-regulated in our analysis of the TCGA RNA-SEQ dataset, and its upregulation was confirmed in our cohort using qRTPCR. However it is noteworthy that discrepancy between the TCGA RNA-SEQ data and qRTPCR for an individual IncRNA. For instance, MINCR and LBX2-AS1 were up-regulated in RNAsequencing and TCGA dataset, while the results of qRT-PCR showed down-regulation of both IncRNAs. HNF1A-AS1 was significantly down-regulated in RNA-sequencing and qRT-PCR, but was up-regulated in TCGA dataset [32].

SPRY4-IT1 is an IncRNA that has been widely reported in many human cancer types. Zhang et al. found SPRY4-IT1 was significantly up-regulated in LUAD tissues (not in LSCC) and further analysis show that the LUAD patients with high SPRY4-IT1 expression exhibit significantly poorer overall survival than those patients with low SPRY4-IT1 expression [33].

Liu et al. found IGF2BP2-AS1 and DGCR5 correlated with better OS in LSCC, while MIR31HG, CDKN2A-AS1 and LINC01600 predicted poor OS in LUAD [34].

Li [35] and Wang [36]separately found that high expression of RGMB-AS1 and LINC01207 in LUAD is associated with a poor prognosis.

LCAL6 (also named as BLACAT1) was higher in LUAD than LSCC $(P=0.014)$ and correlated with larger tumor size and poor survival of LUAD patients [37].

In addition XLOC_008466, FAL1, and XIST were examined in NSCLC by Yang [38], Pan [39] and Wang, [40], respectively In their studies, these IncRNA function as an oncogene in NSCLC, which indicates them as a useful marker and potential therapeutic target.

With the help of microarrays from the Gene expression omnibus database and bioinformatics analyses, Wang et al. [41] found LINC00342 is significantly up-regulated in NSCLC and is potentially a prognostic biomarker.

\section{Analysis of Whole Blood, Serum and Plasma}

\section{Whole Blood and IncRNA Profiling}

Only three studies reported lncRNA's expression in whole blood samples. All of the studies used either RT-PCR or qRT-PCR to measure lncRNA, allowing comparisons to be made between them. Thai P [42] found that the IncRNA SCAL1 was elevated in the airways of smokers and in many lung cancer cell lines. Moreover the expression SCAL1 is regulated by NRF2 that is reported to mediate protection against cigarette smoke-induced toxicity [43]. MALAT1 is another important lncRNA in lung cancer's progression. Many studies showed that MALAT1 was upregulated in tumor tissues when compared with the normal lung tissues [44-46]. But Guo [47] and Weber DG [48] found that the whole blood expression of MALAT1 was lower in the patients with NSCLC than normal people. Comparable results were reported by Zhang et al., the expression of MALAT1 were downregulated in hepatocellular carcinomas patients [49]. Researchers propose that MALAT1 is expressed ubiquitously but its tissue-specific functions depend on the cellular environment [50]. Wu and his colleges [51] 
reported that the level of a novel IncRNA NR-026689 is significantly increased in whole blood of lung cancer in rat and human lung cancer cell lines. These three IncRNA -SCAL1, MALAT1 and IncRNA NR026689, can be used as biomarkers in bodyfluids for early detection of lung cancer. We summarize these lncRNAs in Table 1.

\section{IncRNA Profiling in}

Serum

A positive correlation between IncRNA loc146880 expression and lc3b levels in tumor tissues and serum of lung cancer patients was reported by Deng and his colleagues [52]. Another scientist Tantai
Table 1. LncRNAs as biomarkers in lung cancer' whole blood

\begin{tabular}{lcccc}
\hline LncRNA & Function & Function & Sample & References \\
\hline IncRNA SCAL1(up) & Diagnostic & Lung cancer patients vs healthy controls & Whole bbod & {$[42]$} \\
IncRNA MALAT1(down) & Diagnostic & NSCLC patients vs. healthy controls & Whole bbod & {$[47,48]$} \\
IncRNA MALAT1(up) & Diagnostic and Prognostic & NSCLC patients vs. Controls & tissue & {$[44-46]$} \\
IncRNA NR-026689(up) & Diagnostic & NSCLC patients vs. healthy controls & Whole blood & {$[51]$} \\
\hline
\end{tabular}

Table 2. LncRNAs as biomarkers in lung cancer' serum

\begin{tabular}{lcccc}
\hline LncRNA & Function & Function & Sample & References \\
\hline bc146880 and lc3b & Prognostic & tumor tissues and serum of lung cancer patients & serum & {$[52]$} \\
IncRNA XIST(up) & Diagnostic & NSCLC patients vs. healthy controls & Serum & {$[53]$} \\
IncRNA HIF1A-AS1(up) & Diagnostic & NSCLC patients vs. healthy controls & Serum & {$[53]$} \\
SOX20T and ANRIL & Diagnostic and Prognostic & NSCLC patients vs. healthy controls & Serum & {$[54]$} \\
\hline
\end{tabular}

Table 3. LncRNAs as biomarkers in lung cancer' plasma

\begin{tabular}{lcccc}
\hline LncRNA & Function & Function & Sample & References \\
\hline IncRNA 16(up) & Diagnostic & NSCLC patients vs. healthy controls & Plasma & {$[55]$} \\
IncRNA GAS5(up) & Diagnostic & NSCLC patients vs. healthy controls & Plasma & {$[56]$} \\
IncRNA-UCA1(up) & Diagnostic & NSCLC patients vs. healthy controls & Plasma & {$[57]$} \\
SPRY4-IT1(up) & Diagnostic and Prognostic & NSCLC patients vs. healthy controls & Plasma & {$[58]$} \\
ANRIL(up) & Diagnostic and Prognostic & NSCLC patients vs. healthy controls & Plasma & {$[58]$} \\
NEAT1 (up) & Diagnostic and Prognostic & NSCLC patients vs. healthy controls & Plasma & {$[58]$} \\
RP11-397D12.4(up) & Prognostic & NSCLC patients vs. healthy controls & Plasma & {$[59]$} \\
AC007403.1(up) & Prognostic & NSCLC patients vs. healthy controls & Plasma & {$[59]$} \\
ERICH1-AS1(up) & Prognostic & NSCLC patients vs. healthy controls & Plasma & {$[59]$} \\
\hline
\end{tabular}
[53] reported that the levels of XIST and HIF1A-AS1 were significantly increased in tumor tissues or serum from NSCLC patients. Moreover, serum levels of XIST and HIF1A-AS1 were significantly decreased after surgical resection of tumors (tumor load reduction) as compared to the pre-operative stage. Combined tissue and serum results, Xie's [54] study demonstrated that LncRNA SOX2OT and ANRIL might be ideal biomarkers for NSCLC diagnosis and prognosis. We summarize these lncRNAs in Table 2.

\section{IncRNA Profiling in Plasma}

Early diagnosis of lung cancer can greatly reduce mortality. However, a lack of suitable plasma biomarkers presents a major obstacle. Zhu H reported that lncRNA16 (ENST00000539303) expression was significantly higher in plasma of lung cancer patients $(p<0.05)$ [55]. His findings suggest that lncRNA16 is a biomarker for early diagnosis and a potential therapeutic target. In Liang's report [56], the IncRNA growth arrest-specific transcript 5 (GAS5) also appears to be a promising biomarker for early diagnosis of NSCLC. The plasma levels of GAS5 were significantly lower in NSCLC patients compared with healthy controls. Moreover, Wang H M, et al. [57] demonstrated that lncRNA-UCA1's expression was significantly increased in plasma from NSCLC patients,and the expression in plasma and tumor tissues were strongly correlated in 60 patient samples. Hu et al. hold the opinion that the plasma lncRNA acting as fingerprint in non-small-cell lung cancer, he found Circulating SPRY4-IT1, ANRIL, and NEAT1 were significantly increased in plasma samples and might serve as signature for the prediction of NSCLC [58]. Tang et al. [59] discovered that three IncRNAs(RP11-397D12.4, AC007403.1, and ERICH1-AS1) were up regulated in NSCLC patients plasma, which indicates potential biomarkers for predicting the tumorigenesis of NSCLC. We summarize these lncRNAs in Table 3.

\section{LncRNA Profiling in Sputum}

Lung cancer is a heterogeneous disease featuring field defects in the airway [60]. Most lung cancer patients present the symptoms of cough and expectoration. Sputum is widely collected in clinical work, so biomarkers in sputum can be used for early detect lung cancer. But at present, there is no lung cancer-related lncRNAs detected in sputum. However serveral 


\section{Cellular Physiology Cell Physiol Biochem 2018;49:816-827 \begin{tabular}{ll|l} 
DOI: 10.1159/000493043 & $\begin{array}{l}\text { O 2018 The Author(s). Published by S. Karger AG, Basel } \\
\text { www.karger.com/cpb }\end{array}$
\end{tabular} \\ Peng et al.: Potential of circulating InCRNAs in NSCLC}

microRNAs(eg:miR-21, miR-143,miR-155, miR-210, miR-372) [61-67] and two snoRNAs (snoRDs-66 and 78) have been reported as potential biomarkers for NSCLC [68].

\section{LncRNAs radiochemotherapy in NSCLC}

\section{LncRNA in lung cancer chemotherapy-resistant}

Current treatments against lung cancer are surgical treatment, and chemotherapy in combination with radiotherapy. DNA-damage repair(DDR) mechanisms are very important to maintain genomic stability. Platinum can cause DNA damage, particularly in cancer cells.

Platinum is used widely in chemotherapeutics of NSCLC $[69,70]$. Platinum-based chemotherapy and targeted therapies are milestones in lung cancer treatment $[71,72]$. Platinum arrests DNA replication during cell division [73]. LncRNAs are known to be involved in tumor development and metastasis, as well as chemotherapy resistance [74-76]. The expression of $\mathrm{H} 19$ in cisplatin-resistant A549/DDP cells was upregulated. Knockdown of $\mathrm{H} 19$ restored the response of A549/DDP cells to cisplatin [77]. And lncRNA CASC8 rs10505477 could serve as a possible risk factor for diagnosing lung cancer and the response to platinum-based treatment in lung cancer patients [78]. HOTAIR expression was significantly increased in cisplatin-resistant A549/DDP cells, and that siRNA-mediated silencing of HOTAIR could partly restore the responses of A549/DDP cells to cisplatin [79]. MEG3 expression is decreased in A549/DDP cells, and exogenic overexpression of MEG3 partially reversed the cisplatin resistance of A549/DDP cells through the upregulation of p53 and Bcl-xl expression [80]. Moreover, Yang et al. identified eight lncRNAs that were expressed differentially between A549 and A549/DDP cells [81]. Downregulation of lincAK126698 represses apoptosis induced by cisplatin in A549 cells through decreased naked cuticle homolog 2 expression and increased $\beta$-catenin expression that results in altered Wnt signaling [81]. Fang et al. reported that HOTAIR silencing reduced methylation of HOXA1 and enhanced the sensitivity of cancer cells to anticancer drugs in SCLC [82]. Ren reported that silencing the expression of KCNQ10T1 significantly inhibited chemoresistance to paclitaxel in LAD drug-resistant cells [83]. Ma et al. demonstrated that lncRNA TRPM2AS enhanced the resistance of A549 cells to cisplatin [84]. Shi et al. reported that LncRNA ROR (regulator of reprogramming) silencing has the ability to enhance the sensitivity of lung adenocarcinoma cells to DDP by targeting PI3K/Akt/mTOR signaling pathway [85] that plays a key role in cell apoptosis and metastasis [86]. HOTTIP is reported to play a key role for in SCLC progression and chemoresistance by sponging miR-216a and promote BCL-2 expression, suggest it as a new prognostic biomarker for clinical management of SCLC [87].

\section{LncRNA in lung cancer radiotherapy-resistant}

Radiotherapy is essential for most lung cancer patients, especially for those with advanced stage NSCLC. In these patients, radiotherapy is especially critical $[88,89]$. Radioactive rays could lead to physical, chemical and biological damages to both tumor cells and normal cells [90]. Recent reports show that LncRNAs are involved in the DNA damage response after radioactive rays, which may regulate the response to radiotherapy [91]. Cheng et al. demonstrated an inverse correlation between BANCR (BRAF activated non-coding RNAs) and radioresistance in mouse lung cancer tissues, when the mice were grafted with Lewis Lung cancer cells [92]. However, the detailed mechanisms about IncRNA and resistance to radiotherapy remain to be characterized.

\section{LncRNAs in lung cancer EGFR resistance}

EGFR-TKIs (EGFR tyrosine kinase inhibitors) and Programmed cell death protein 1 inhibitors are well known target therapies for NSCLC. Epidermal growth factor receptor (EGFR) super-family are regarded as a therapeutic target to NSCLC. It was firstly reported in 2004, patients who carry the EGFR mutations are sensitive to gefitinib [93]. And the never smokers with adenocarcinomas acquire EGFR gene mutation more frequently than 
smokers, which causes them to be more sensitive to gefitinib or erlotinib [94]. However, acquired resistances are inevitable [95]. Kim $\mathrm{H}$ further found that the microRNA expression profile in the ALK rearrangement group were different from those in the EGFR and KRAS groups through clustering and discriminant analyses [96]. With the help of IncRNA microarray and bioinformatics analysis, Cheng showed the different

Table 4. LncRNAs in drug resistance

\begin{tabular}{|c|c|c|c|}
\hline$\overline{I n c R N A}$ & Function & Sample & References \\
\hline H19(up) & cisplatin resistance & A549/DDP cells & {$[77]$} \\
\hline $\begin{array}{l}\text { IncRNA CASC8 rs10505477 } \\
\text { (up) }\end{array}$ & cisplatin resistance & Lung cancer patients & [78] \\
\hline HOTAIR(up) & cisplatin resistance & A549/DDP cells & [79] \\
\hline HOTAIR(up) & anticancer drugs resistance & SCLC cells & [82] \\
\hline MEG3(down) & cisplatin resistance & A549/DDP cells & [80] \\
\hline lincAK126698(down) & cisplatin resistance & A549/DDP cells & [81] \\
\hline LncRNA TRPM2-AS(up) & cisplatin resistance & A549/DDP cells & [84] \\
\hline KCNQ10T1(up) & Paclitaxel resistance & A549/Paclitaxel celk & [83] \\
\hline LncRNA ROR & Increases DDP sensitivity & Lung a denocarcinoma cells & [85] \\
\hline HOTTIP(up) & $\begin{array}{l}\text { cisplatin and etoposide } \\
\text { resistance }\end{array}$ & $\begin{array}{l}\text { SCLC chemosensitive tissues compared with non- } \\
\text { cancerous lung tissues/H69AR, H446AR cells }\end{array}$ & [87] \\
\hline MIR31HG(up) & increases gefitinib resistance & NCSLC cell lines & [102] \\
\hline CASC9(up) & increases gefitinib resistance & PC9G & [102] \\
\hline EWAST1(Linc00227)(down) & increases gefitinib resistance & PC9G & [103] \\
\hline LncRNA BC087858(up) & $\begin{array}{l}\text { induce non-T790M mutation } \\
\text { acquired resistance to EGFR-TKIs }\end{array}$ & NCSLC cell lines & [104] \\
\hline GAS5 (up) & increases gefitinib sensitivity & in vitro and in vivo & [105] \\
\hline linc00635-001(down) & increases gefitinib resistance & HCC827-8-1 cells & [107] \\
\hline IncRNA-BC200(up) & mediate resistance to gefitinib & NCSLC cell lines & [97] \\
\hline
\end{tabular}
lncRNA expression in EGFR-TKIs-sensitive and -resistant human lung cancer cells, and speculated this disparate expression profile can play a pivotal role in resistance to EGFR-TKIs [97]. Cheng $\mathrm{N}$ and his colleagues first identified that 22, 587 lncRNAs were differentially expressed between gefitinib-sensitive and gefitinib-resistant lung cancer cells [97]. Bioinformatics analysis suggests that these differentially expressed IncRNAs regulate resistance to EGFR-TKIs by regulating their neighboring genes. Previous studies reported that the mechanism of EGFRTKIs resistance is associated with cell proliferation and cell apoptosis [98-100]. In addition, Wu demonstrated that 1476 lncRNAs were dysregulated in EGFR-TKI-resistant cell line of lung adenocarcinoma, which further illustrated that lncRNAs serve as potential biomarkers in EGFR-TKI therapy-resistance [101]. Wang B found MIR31HG IncRNA expression increased gefitinib resistance in NSCLC cell lines through the EGFR/PI3K/AKT signaling pathway [102]. CASC9 expression was upregulated in PC9G(pc-9gefitinib resistance) and knockdown of its expression increased the sensitivity of PC9G cells to gefitinib, while EWAST1(Linc00227) is downregulated in PC9G cells and overexpressed EWAST1 also leads to increased sensitivity of PC9G cells to gefitinib [103]. LncRNA BC087858 can promote cells invasion and induce non-T790M mutation acquired resistance to EGFR-TKIs by activating PI3K/AKT and MEK/ERK pathways and EMT via up- regulating ZEB1 and Snail in NSCLC [104]. Dong demonstrated that GAS5 can reduce tumor growth under treatment with gefitinib and IGF$1 \mathrm{R}$ is a key downstream mediator of GAS5 [105]. Chao L et al. also reported that silencing the expression of GAS5 reduces the chemo-sensitivity of NSCLC cell to DDP through regulating miR-21/PTEN axis [106]. Linc00635-001 silencing accompanied by gefitinib treatment suppressed Akt activation and sensitized HCC827-8-1 cells to gefitinib-induced cytotoxicity [107]. Cheng $\mathrm{N}$ also found that IncRNA-BC200 mediates resistance to gefitinib [97]. Lin A et al. found LINK-A interacts with PtdIns $(3,4,5) \mathrm{P} 3$ to activate AKT and confer resistance to AKT inhibitors. Future studies are required to fully elucidate the mechanisms despite an emerging association between IncRNAs and drug resistance [108]. We summarize these lncRNAs in Table 4. 


\section{Cellular Physiology Cell Physiol Biochem 2018;49:816-827 \begin{tabular}{ll|l} 
and Biochemistry Published online: 30 August, 2018 & $\begin{array}{l}\text { (c) } 2018 \text { The Author(s). Published by S. Karger AG, Basel } \\
\text { www.karger.com/cpb }\end{array}$
\end{tabular}}

Peng et al.: Potential of circulating IncRNAs in NSCLC

\section{Conclusion}

In conclusion, expression of numerous lncRNAs are dysregulated in lung cancer. Many of them are potential biomarkers of diagnosis and prognosis, especially drug resistance. It is suggested that IncRNAs can exert their functions through interactions with coding transcripts and proteins. However, the exact mechanisms of lncRNAs demand further studies to determine whether the differentially expressed lncRNAs regulate drug resistance in NSCLC and the lncRNAs are targets to overcome acquired drug resistance.

\section{Acknowledgements}

We are grateful for all the contributions that supported this study. This work was supported by National Natural Science Foundation of China Grants (Nos. 81702278, 81572281, 81401901, 81372515 and 81200366)

\section{Disclosure Statement}

The authors declare to have no competing interests.

\section{References}

1 Siegel RL, Miller KD, Jemal A: Cancer Statistics, 2017. CA Cancer J Clin 2017;67:7-30.

$\checkmark 2$ Scagliotti GV, Selvaggi G: New data integrating multitargeted antifolates into treatment of first-line and relapsed non-small-cell lung cancer. Clin Lung Cancer 2008;9:S122-128.

-3 Hanna N, Shepherd FA, Fossella FV, Pereira JR, De Marinis F, von Pawel J, Gatzemeier U, Tsao TC, Pless M, Muller T, Lim HL, Desch C, Szondy K, Gervais R, Shaharyar, Manegold C, Paul S, Paoletti P, Einhorn L, Bunn PA, Jr.: Randomized phase III trial of pemetrexed versus docetaxel in patients with non-small-cell lung cancer previously treated with chemotherapy. J Clin Oncol 2004;22:1589-1597.

4 Ciuleanu T, Brodowicz T, Zielinski C, Kim JH, Krzakowski M, Laack E, Wu YL, Bover I, Begbie S, Tzekova V, Cucevic B, Pereira JR, Yang SH, Madhavan J, Sugarman KP, Peterson P, John WJ, Krejcy K, Belani CP: Maintenance pemetrexed plus best supportive care versus placebo plus best supportive care for non-smallcell lung cancer: a randomised, double-blind, phase 3 study. Lancet 2009;374:1432-1440.

5 Ardizzoni A, Boni L, Tiseo M, Fossella FV, Schiller JH, Paesmans M, Radosavljevic D, Paccagnella A, Zatloukal P, Mazzanti P, Bisset D, Rosell R, Group CM-a: Cisplatin- versus carboplatin-based chemotherapy in first-line treatment of advanced non-small-cell lung cancer: an individual patient data meta-analysis. J Natl Cancer Inst 2007;99:847-857.

6 Zhang Y, Chen G, Chen X, Fang W, Gao F, Yang Y, Zhao Y, Ma Y, Hong S, Zhang Z, Miao S, Wu M, Huang X, Luo Y, Zhou C, Gong R, Huang Y, Chen L, Zhou N, Zhao H, Zhang L: The comparison of EGFR-TKI failure modes and subsequent management between exon 19 deletion and exon 21 L858R mutation in advanced non-smallcell lung cancer. J Cancer 2017;8:1865-1871.

7 Tuononen K, Sarhadi VK, Wirtanen A, Ronty M, Salmenkivi K, Knuuttila A, Remes S, Telaranta-Keerie AI, Bloor S, Ellonen P, Knuutila S: Targeted resequencing reveals ALK fusions in non-small cell lung carcinomas detected by FISH, immunohistochemistry, and real-time RT-PCR: a comparison of four methods. Biomed Res Int 2013;2013:757490.

-8 Patz EF, Jr., Greco E, Gatsonis C, Pinsky P, Kramer BS, Aberle DR: Lung cancer incidence and mortality in National Lung Screening Trial participants who underwent low-dose CT prevalence screening: a retrospective cohort analysis of a randomised, multicentre, diagnostic screening trial. Lancet Oncol 2016;17:590-599.

-9 Eberth JM, Qiu R, Adams SA, Salloum RG, Bell N, Arrington AK, Linder SK, Munden RF: Lung cancer screening using low-dose CT: the current national landscape. Lung Cancer 2014;85:379-384. 


\section{Cellular Physiology Cell Physiol Biochem 2018;49:816-827 \begin{tabular}{ll|l} 
and Biochemistry Published online: 30 August, 2018 & $\begin{array}{l}\text { (c) } 2018 \text { The Author(s). Published by S. Karger AG, Basel } \\
\text { www.karger.com/cpb }\end{array}$ \\
\hline
\end{tabular}}

Peng et al.: Potential of circulating IncRNAs in NSCLC

10 Cremonesi M, Gilardi L, Ferrari ME, Piperno G, Travaini LL, Timmerman R, Botta F, Baroni G, Grana CM, Ronchi S, Ciardo D, Jereczek-Fossa BA, Garibaldi C, Orecchia R: Role of interim (18)F-FDG-PET/CT for the early prediction of clinical outcomes of Non-Small Cell Lung Cancer (NSCLC) during radiotherapy or chemo-radiotherapy. A systematic review. Eur J Nucl Med Mol Imaging 2017;44:1915-1927.

-11 Sheikhbahaei S, Ahn SJ, Young B, Taghipour M, Marcus C, Subramaniam RM: Comparative effectiveness: 18F-FDG-PET/CT versus CT for post-treatment follow-up of patients with lung cancer. Nucl Med Commun 2017;38:720-725.

12 Umakoshi H, Iwano S, Yokoi K, Ito S, Ito R, Kawaguchi K, Fukui T, Naganawa S: FDG PET/CT Overcomes Discordance Between Clinical and Pathologic TNM Classification of Small-size Primary Lung Cancer: Influence on Postoperative Prognosis. Clin Lung Cancer 2018;19:e37-e45.

13 Chudasama D, Burnside N, Beeson J, Karteris E, Rice A, Anikin V: Perioperative detection of circulating tumour cells in patients with lung cancer. Oncol Lett 2017;14:1281-1286.

$\checkmark 14$ Best MG, Sol N, In ‘t Veld S, Vancura A, Muller M, Niemeijer AN, Fejes AV, Tjon Kon Fat LA, Huis In 't Veld AE, Leurs C, Le Large TY, Meijer LL, Kooi IE, Rustenburg F, Schellen P, Verschueren H, Post E, Wedekind LE, Bracht J, Esenkbrink M, et al.: Swarm Intelligence-Enhanced Detection of Non-Small-Cell Lung Cancer Using Tumor-Educated Platelets. Cancer Cell 2017;32:238-252 e239.

15 Tang ZM, Ling ZG, Wang CM, Wu YB, Kong JL: Serum tumor-associated autoantibodies as diagnostic biomarkers for lung cancer: A systematic review and meta-analysis. PLoS One 2017;12:e0182117.

-16 Zhou D, Xie M, He B, Gao Y, Yu Q, He B, Chen Q: Microarray data re-annotation reveals specific lncRNAs and their potential functions in non-small cell lung cancer subtypes. Mol Med Rep 2017;16:5129-5136.

17 Schmitz SU, Grote P, Herrmann BG: Mechanisms of long noncoding RNA function in development and disease. Cell Mol Life Sci 2016;73:2491-2509.

18 Iyer MK, Niknafs YS, Malik R, Singhal U, Sahu A, Hosono Y, Barrette TR, Prensner JR, Evans JR, Zhao S, Poliakov A, Cao X, Dhanasekaran SM, Wu YM, Robinson DR, Beer DG, Feng FY, Iyer HK, Chinnaiyan AM: The landscape of long noncoding RNAs in the human transcriptome. Nat Genet 2015;47:199-208.

19 Peng Z, Zhang C, Duan C: Functions and mechanisms of long noncoding RNAs in lung cancer. Onco Targets Ther 2016;9:4411-4424.

20 Saha P, Verma S, Pathak RU, Mishra RK: Long Noncoding RNAs in Mammalian Development and Diseases. Adv Exp Med Biol 2017;1008:155-198.

-21 Guttman M, Amit I, Garber M, French C, Lin MF, Feldser D, Huarte M, Zuk O, Carey BW, Cassady JP, Cabili MN, Jaenisch R, Mikkelsen TS, Jacks T, Hacohen N, Bernstein BE, Kellis M, Regev A, Rinn JL, Lander ES: Chromatin signature reveals over a thousand highly conserved large non-coding RNAs in mammals. Nature 2009;458:223-227.

22 Wapinski O, Chang HY: Long noncoding RNAs and human disease. Trends Cell Biol 2011;21:354-361.

$>23$ Wilusz JE, Sunwoo H, Spector DL: Long noncoding RNAs: functional surprises from the RNA world. Genes Dev 2009;23:1494-1504.

24 Akhade VS, Pal D, Kanduri C: Long Noncoding RNA: Genome Organization and Mechanism of Action. Adv Exp Med Biol 2017;1008:47-74.

25 Khachane AN, Harrison PM: Mining mammalian transcript data for functional long non-coding RNAs. PLoS One 2010;5:e10316.

26 Gibb EA, Vucic EA, Enfield KS, Stewart GL, Lonergan KM, Kennett JY, Becker-Santos DD, MacAulay CE, Lam S, Brown CJ, Lam WL: Human cancer long non-coding RNA transcriptomes. PLoS One 2011;6:e25915.

27 Li J, Yang B, Zhou Q, Wu Y, Shang D, Guo Y, Song Z, Zheng Q, Xiong J: Autophagy promotes hepatocellular carcinoma cell invasion through activation of epithelial-mesenchymal transition. Carcinogenesis 2013;34:1343-1351.

28 Zhao WJ, Wang X, Ma KW: [Progression of diagnosis and treatment for adenosquamous lung carcinoma]. Zhonghua Zhong Liu Za Zhi 2017;39:241-244.

29 Jin X, Xu X, Xu H, Lv L, Lu H: The Diagnostic Value of Carcinoembryonic Antigen and Squamous Cell Carcinoma Antigen in Lung Adenosquamous Carcinoma. Clin Lab 2017;63:801-808.

-30 Fan L, Yang H, Yao F, Zhao Y, Gu H, Han K, Zhao H: Clinical outcomes of epidermal growth factor receptor tyrosine kinase inhibitors in recurrent adenosquamous carcinoma of the lung after resection. Onco Targets Ther 2017;10:239-245.

31 Beasley MB, Brambilla E, Travis WD: The 2004 World Health Organization classification of lung tumors. Semin Roentgenol 2005;40:90-97. 


\section{Cellular Physiology Cell Physiol Biochem 2018;49:816-827 \begin{tabular}{ll|l} 
and Biochemistry & $\begin{array}{l}\text { DOI: 10.1159/000493043 } \\
\text { Published online: 30 August, } 2018\end{array}$ & $\begin{array}{l}\text { (c) } 2018 \text { The Author(s). Published by S. Karger AG, Basel } \\
\text { www.karger.com/cpb }\end{array}$ \\
\hline
\end{tabular}}

Peng et al.: Potential of circulating IncRNAs in NSCLC

32 Tian Z, Wen S, Zhang Y, Shi X, Zhu Y, Xu Y, Lv H, Wang G: Identification of dysregulated long non-coding RNAs/microRNAs/mRNAs in TNM I stage lung adenocarcinoma. Oncotarget 2017;8:51703-51718.

-33 Zhang X, Chi Q, Zhao Z: Up-regulation of long non-coding RNA SPRY4-IT1 promotes tumor cell migration and invasion in lung adenocarcinoma. Oncotarget 2017;8:51058-51065.

34 Liu B, Chen Y, Yang J: LncRNAs are altered in lung squamous cell carcinoma and lung adenocarcinoma. Oncotarget 2017;8:24275-24291.

35 Li P, Zhang G, Li J, Yang R, Chen S, Wu S, Zhang F, Bai Y, Zhao H, Wang Y, Dun S, Chen X, Sun Q, Zhao G: Long Noncoding RNA RGMB-AS1 Indicates a Poor Prognosis and Modulates Cell Proliferation, Migration and Invasion in Lung Adenocarcinoma. PLoS One 2016;11:e0150790.

-36 Wang G, Chen H, Liu J: The long noncoding RNA LINC01207 promotes proliferation of lung adenocarcinoma. Am J Cancer Res 2015;5:3162-3173.

37 Qiu M, Feng D, Zhang H, Xia W, Xu Y, Wang J, Dong G, Zhang Y, Yin R, Xu L: Comprehensive analysis of lncRNA expression profiles and identification of functional lncRNAs in lung adenocarcinoma. Oncotarget 2016;7:16012-16022.

38 Yang R, Li P, Zhang G, Lu C, Wang H, Zhao G: Long Non-Coding RNA XLOC_008466 Functions as an Oncogene in Human Non-Small Cell Lung Cancer by Targeting miR-874. Cell Physiol Biochem 2017;42:126136.

39 Pan C, Yao G, Liu B, Ma T, Xia Y, Wei K, Wang J, Xu J, Chen L, Chen Y: Long Noncoding RNA FAL1 Promotes Cell Proliferation, Invasion and Epithelial-Mesenchymal Transition Through the PTEN/AKT Signaling Axis in Non-Small Cell Lung Cancer. Cell Physiol Biochem 2017;43:339-352.

-40 Wang H, Shen Q, Zhang X, Yang C, Cui S, Sun Y, Wang L, Fan X, Xu S: The Long Non-Coding RNA XIST Controls Non-Small Cell Lung Cancer Proliferation and Invasion by Modulating miR-186-5p. Cell Physiol Biochem 2017;41:2221-2229.

41 Wang L, Chen Z, An L, Wang Y, Zhang Z, Guo Y, Liu C: Analysis of Long Non-Coding RNA Expression Profiles in Non-Small Cell Lung Cancer. Cell Physiol Biochem 2016;38:2389-2400.

42 Thai P, Statt S, Chen CH, Liang E, Campbell C, Wu R: Characterization of a novel long noncoding RNA, SCAL1, induced by cigarette smoke and elevated in lung cancer cell lines. Am J Respir Cell Mol Biol 2013;49:204211.

43 Zhang M, Mathur A, Zhang Y, Xi S, Atay S, Hong JA, Datrice N, Upham T, Kemp CD, Ripley RT, Wiegand G, Avital I, Fetsch P, Mani H, Zlott D, Robey R, Bates SE, Li X, Rao M, Schrump DS: Mithramycin represses basal and cigarette smoke-induced expression of ABCG2 and inhibits stem cell signaling in lung and esophageal cancer cells. Cancer Res 2012;72:4178-4192.

44 Gutschner T, Hammerle M, Eissmann M, Hsu J, Kim Y, Hung G, Revenko A, Arun G, Stentrup M, Gross M, Zornig M, MacLeod AR, Spector DL, Diederichs S: The noncoding RNA MALAT1 is a critical regulator of the metastasis phenotype of lung cancer cells. Cancer Res 2013;73:1180-1189.

-45 Jen J, Tang YA, Lu YH, Lin CC, Lai WW, Wang YC: Oct4 transcriptionally regulates the expression of long noncoding RNAs NEAT1 and MALAT1 to promote lung cancer progression. Mol Cancer 2017;16:104.

46 Guo F, Guo L, Li Y, Zhou Q Li Z: MALAT1 is an oncogenic long non-coding RNA associated with tumor invasion in non-small cell lung cancer regulated by DNA methylation. Int J Clin Exp Pathol 2015;8:1590315910.

47 Guo F, Yu F, Wang J, Li Y, Li Y, Li Z, Zhou Q: Expression of MALAT1 in the peripheral whole blood of patients with lung cancer. Biomed Rep 2015;3:309-312.

-48 Weber DG, Johnen G, Casjens S, Bryk O, Pesch B, Jockel KH, Kollmeier J, Bruning T: Evaluation of long noncoding RNA MALAT1 as a candidate blood-based biomarker for the diagnosis of non-small cell lung cancer. BMC Res Notes 2013;6:518.

49 Zhang PJ, Wei R, Wen XY, Ping L, Wang CB, Dong ZN, Deng XX, Bo W, Bin C, Tian YP: Genes expression profiling of peripheral blood cells of patients with hepatocellular carcinoma. Cell Biol Int 2012;36:803-809.

50 Eissmann M, Gutschner T, Hammerle M, Gunther S, Caudron-Herger M, Gross M, Schirmacher P, Rippe K, Braun T, Zornig M, Diederichs S: Loss of the abundant nuclear non-coding RNA MALAT1 is compatible with life and development. RNA Biol 2012;9:1076-1087.

51 Wu J, Li X, Xu Y, Yang T, Yang Q, Yang C, Jiang Y: Identification of a long non-coding RNA NR_026689 associated with lung carcinogenesis induced by NNK. Oncotarget 2016;7:14486-14498. 


\section{Cellular Physiology Cell Physiol Biochem 2018;49:816-827 \begin{tabular}{ll|l} 
and Biochemistry Published online: 30 August, 2018 & $\begin{array}{l}\text { (c) } 2018 \text { The Author(s). Published by S. Karger AG, Basel } \\
\text { www.karger.com/cpb }\end{array}$ \\
\hline
\end{tabular}}

Peng et al.: Potential of circulating IncRNAs in NSCLC

52 Deng X, Feng N, Zheng M, Ye X, Lin H, Yu X, Gan Z, Fang Z, Zhang H, Gao M, Zheng ZJ, Yu H, Ding W, Qian B: PM2.5 exposure-induced autophagy is mediated by lncRNA loc146880 which also promotes the migration and invasion of lung cancer cells. Biochim Biophys Acta 2017;1861:112-125.

53 Tantai J, Hu D, Yang Y, Geng J: Combined identification of long non-coding RNA XIST and HIF1A-AS1 in serum as an effective screening for non-small cell lung cancer. Int J Clin Exp Pathol 2015;8:7887-7895.

54 Xie Y, Zhang Y, Du L, Jiang X, Yan S, Duan W, Li J, Zhan Y, Wang L, Zhang S, Li S, Wang L, Xu S, Wang C: Circulating long noncoding RNA act as potential novel biomarkers for diagnosis and prognosis of non-small cell lung cancer. Mol Oncol 2018;12:648-658.

-55 Zhu H, Zhang L, Yan S, Li W, Cui J, Zhu M, Xia N, Yang Y, Yuan J, Chen X, Luo J, Chen R, Xing R, Lu Y, Wu N: LncRNA16 is a potential biomarker for diagnosis of early-stage lung cancer that promotes cell proliferation by regulating the cell cycle. Oncotarget 2017;8:7867-7877.

56 Liang W, Lv T, Shi X, Liu H, Zhu Q Zeng J, Yang W, Yin J, Song Y: Circulating long noncoding RNA GAS5 is a novel biomarker for the diagnosis of nonsmall cell lung cancer. Medicine (Baltimore) 2016;95:e4608.

57 Wang HM, Lu JH, Chen WY, Gu AQ: Upregulated IncRNA-UCA1 contributes to progression of lung cancer and is closely related to clinical diagnosis as a predictive biomarker in plasma. Int J Clin Exp Med 2015;8:11824-11830.

58 Hu X, Bao J, Wang Z, Zhang Z, Gu P, Tao F, Cui D, Jiang W: The plasma lncRNA acting as fingerprint in nonsmall-cell lung cancer. Tumour Biol 2016;37:3497-3504.

59 Tang Q, Ni Z, Cheng Z, Xu J, Yu H, Yin P: Three circulating long non-coding RNAs act as biomarkers for predicting NSCLC. Cell Physiol Biochem 2015;37:1002-1009.

-60 McKay JD, Hung RJ, Han Y, Zong X, Carreras-Torres R, Christiani DC, Caporaso NE, Johansson M, Xiao X, Li Y, Byun J, Dunning A, Pooley KA, Qian DC, Ji X, Liu G, Timofeeva MN, Bojesen SE, Wu X, Le Marchand L, et al.: Large-scale association analysis identifies new lung cancer susceptibility loci and heterogeneity in genetic susceptibility across histological subtypes. Nat Genet 2017;49:1126-1132.

61 Hubers AJ, Prinsen CF, Sozzi G, Witte BI, Thunnissen E: Molecular sputum analysis for the diagnosis of lung cancer. Br J Cancer 2013;109:530-537.

62 Xie Y, Todd NW, Liu Z, Zhan M, Fang H, Peng H, Alattar M, Deepak J, Stass SA, Jiang F: Altered miRNA expression in sputum for diagnosis of non-small cell lung cancer. Lung Cancer 2010;67:170-176.

63 Xing L, Todd NW, Yu L, Fang H, Jiang F: Early detection of squamous cell lung cancer in sputum by a panel of microRNA markers. Mod Pathol 2010;23:1157-1164.

64 Yu L, Todd NW, Xing L, Xie Y, Zhang H, Liu Z, Fang H, Zhang J, Katz RL, Jiang F: Early detection of lung adenocarcinoma in sputum by a panel of microRNA markers. Int J Cancer 2010;127:2870-2878.

65 Li N, Ma J, Guarnera MA, Fang H, Cai L, Jiang F: Digital PCR quantification of miRNAs in sputum for diagnosis of lung cancer. J Cancer Res Clin Oncol 2014;140:145-150.

66 Shen J, Liao J, Guarnera MA, Fang H, Cai L, Stass SA, Jiang F: Analysis of MicroRNAs in sputum to improve computed tomography for lung cancer diagnosis. J Thorac Oncol 2014;9:33-40.

-67 Roa WH, Kim JO, Razzak R, Du H, Guo L, Singh R, Gazala S, Ghosh S, Wong E, Joy AA, Xing JZ, Bedard EL: Sputum microRNA profiling: a novel approach for the early detection of non-small cell lung cancer. Clin Invest Med 2012;35:E271.

-68 Su Y, Guarnera MA, Fang H, Jiang F: Small non-coding RNA biomarkers in sputum for lung cancer diagnosis. Mol Cancer 2016;15:36.

69 Kang J, Demaria S, Formenti S: Current clinical trials testing the combination of immunotherapy with radiotherapy. J Immunother Cancer 2016;4:51.

70 Valdes M, Nicholas G, Goss GD, Wheatley-Price P: Chemotherapy in recurrent advanced non-small-cell lung cancer after adjuvant chemotherapy. Curr Oncol 2016;23:386-390.

71 Su S, Li T, Lu B, Wang X, Li J, Chen M, Lu Y, Bai Y, Hu Y, Ouyang W, Ma Z, Li Q Li H, Wang Y: ThreeDimensional Radiation Therapy to the Primary Tumor With Concurrent Chemotherapy in Patients With Stage IV Non-Small Cell Lung Cancer: Results of a Multicenter Phase 2 Study From PPRA-RTOG, China. Int J Radiat Oncol Biol Phys 2015;93:769-777.

72 Song X, Wang Z: Clinical efficacy evaluation of tyrosine kinase inhibitors for non-adenocarcinoma lung cancer patients harboring EGFR-sensitizing mutations. Onco Targets Ther 2017;10:3119-3122.

-73 Helleday T, Petermann E, Lundin C, Hodgson B, Sharma RA: DNA repair pathways as targets for cancer therapy. Nat Rev Cancer 2008;8:193-204.

-74 Takahashi K, Yan I, Haga H, Patel T: Long noncoding RNA in liver diseases. Hepatology 2014;60:744-753. 


\section{Cellular Physiology Cell Physiol Biochem 2018;49:816-827 \begin{tabular}{ll|l} 
and Biochemistry & $\begin{array}{l}\text { DOI: 10.1159/000493043 } \\
\text { Published online: 30 August, } 2018\end{array}$ & $\begin{array}{l}\text { (c) } 2018 \text { The Author(s). Published by S. Karger AG, Basel } \\
\text { www.karger.com/cpb }\end{array}$
\end{tabular}}

Peng et al.: Potential of circulating IncRNAs in NSCLC

75 Zhao J, Lawless MW: Long noncoding RNAs and their role in the liver cancer axis. Nat Rev Gastroenterol Hepatol 2013;10.1038/nrgastro.2013.87-c1

76 Ren S, Wang F, Shen J, Sun Y, Xu W, Lu J, Wei M, Xu C, Wu C, Zhang Z, Gao X, Liu Z, Hou J, Huang J, Sun Y: Long non-coding RNA metastasis associated in lung adenocarcinoma transcript 1 derived miniRNA as a novel plasma-based biomarker for diagnosing prostate cancer. Eur J Cancer 2013;49:2949-2959.

77 Wang Q, Cheng N, Li X, Pan H, Li C, Ren S, Su C, Cai W, Zhao C, Zhang L, Zhou C: Correlation of long noncoding RNA H19 expression with cisplatin-resistance and clinical outcome in lung adenocarcinoma. Oncotarget 2017;8:2558-2567.

-78 Hu L, Chen SH, Lv QL, Sun B, Qu Q, Qin CZ, Fan L, Guo Y, Cheng L, Zhou HH: Clinical Significance of Long Non-Coding RNA CASC8 rs10505477 Polymorphism in Lung Cancer Susceptibility, Platinum-Based Chemotherapy Response, and Toxicity. Int J Environ Res Public Health 2016;13:pii:E545.

79 Liu Z, Sun M, Lu K, Liu J, Zhang M, Wu W, De W, Wang Z, Wang R: The long noncoding RNA HOTAIR contributes to cisplatin resistance of human lung adenocarcinoma cells via downregualtion of p21(WAF1/ CIP1) expression. PLoS One 2013;8:e77293.

80 Liu J, Wan L, Lu K, Sun M, Pan X, Zhang P, Lu B, Liu G, Wang Z: The Long Noncoding RNA MEG3 Contributes to Cisplatin Resistance of Human Lung Adenocarcinoma. PLoS One 2015;10:e0114586.

81 Yang Y, Li H, Hou S, Hu B, Liu J, Wang J: The noncoding RNA expression profile and the effect of IncRNA AK126698 on cisplatin resistance in non-small-cell lung cancer cell. PLoS One 2013;8:e65309.

-82 Fang S, Gao H, Tong Y, Yang J, Tang R, Niu Y, Li M, Guo L: Long noncoding RNA-HOTAIR affects chemoresistance by regulating HOXA1 methylation in small cell lung cancer cells. Lab Invest 2016;96:6068.

83 Ren K, Xu R, Huang J, Zhao J, Shi W: Knockdown of long non-coding RNA KCNQ10T1 depressed chemoresistance to paclitaxel in lung adenocarcinoma. Cancer Chemother Pharmacol 2017;80:243-250.

-84 Ma LY, Xie XW, Ma L, Pang JL, Xiong XM, Zheng HD, Shen XL, Wen ZG, Wang HY: Downregulated long noncoding RNA TRPM2-AS inhibits cisplatin resistance of non-small cell lung cancer cells via activation of p53p66shc pathway. Eur Rev Med Pharmacol Sci 2017;21:2626-2634.

85 Shi H, Pu J, Zhou XL, Ning YY, Bai C: Silencing long non-coding RNA ROR improves sensitivity of non-smallcell lung cancer to cisplatin resistance by inhibiting PI3K/Akt/mTOR signaling pathway. Tumour Biol 2017;39:1010428317697568.

86 Lien EC, Lyssiotis CA, Cantley LC: Metabolic Reprogramming by the PI3K-Akt-mTOR Pathway in Cancer. Recent Results Cancer Res 2016;207:39-72.

-87 Sun Y, Hu B, Wang Q, Ye M, Qiu Q, Zhou Y, Zeng F, Zhang X, Guo Y, Guo L: Long non-coding RNA HOTTIP promotes BCL-2 expression and induces chemoresistance in small cell lung cancer by sponging miR-216a. Cell Death Dis 2018;9:85.

88 Yoon SM, Shaikh T, Hallman M: Therapeutic management options for stage III non-small cell lung cancer. World J Clin Oncol 2017;8:1-20.

89 Wu AJ, Garay E, Foster A, Hsu M, Zhang Z, Chaft JE, Huang J, Rosenzweig KE, Rimner A: Definitive Radiotherapy for Local Recurrence of NSCLC After Surgery. Clin Lung Cancer 2017;18:e161-e168.

$\$ 90$ Youroukou A, Gkiozos I, Kalaitzi Z, Tsalafoutas I, Papalla K, Charpidou A, Kouloulias V: The potential role of brachytherapy in the irradiation of patients with lung cancer: a systematic review. Clin Transl Oncol 2017;19:945-950.

-91 Li L, Zhu T, Gao YF, Zheng W, Wang CJ, Xiao L, Huang MS, Yin JY, Zhou HH, Liu ZQ: Targeting DNA Damage Response in the Radio(Chemo)therapy of Non-Small Cell Lung Cancer. Int J Mol Sci 2016;17:pii:E839.

-92 Chen JX, Chen M, Zheng YD, Wang SY, Shen ZP: Up-regulation of BRAF activated non-coding RNA is associated with radiation therapy for lung cancer. Biomed Pharmacother 2015;71:79-83.

$\$ 93$ Lynch TJ, Bell DW, Sordella R, Gurubhagavatula S, Okimoto RA, Brannigan BW, Harris PL, Haserlat SM, Supko JG, Haluska FG, Louis DN, Christiani DC, Settleman J, Haber DA: Activating mutations in the epidermal growth factor receptor underlying responsiveness of non-small-cell lung cancer to gefitinib. $\mathrm{N}$ Engl J Med 2004;350:2129-2139.

-94 Pao W, Miller V, Zakowski M, Doherty J, Politi K, Sarkaria I, Singh B, Heelan R, Rusch V, Fulton L, Mardis E, Kupfer D, Wilson R, Kris M, Varmus H: EGF receptor gene mutations are common in lung cancers from "never smokers" and are associated with sensitivity of tumors to gefitinib and erlotinib. Proc Natl Acad Sci U S A 2004;101:13306-13311. 


\section{Cellular Physiology Cell Physiol Biochem 2018;49:816-827 \begin{tabular}{l|l|l} 
and Biochemistry Published online: 30 August, 2018 & $\begin{array}{l}\text { @ } 2018 \text { The Author(s). Published by S. Karger AG, Basel } \\
\text { www.karger.com/cpb }\end{array}$ \\
\hline
\end{tabular}}

Peng et al.: Potential of circulating InCRNAs in NSCLC

-95 Soria JC, Wu YL, Nakagawa K, Kim SW, Yang JJ, Ahn MJ, Wang J, Yang JC, Lu Y, Atagi S, Ponce S, Lee DH, Liu Y, Yoh K, Zhou JY, Shi X, Webster A, Jiang H, Mok TS: Gefitinib plus chemotherapy versus placebo plus chemotherapy in EGFR-mutation-positive non-small-cell lung cancer after progression on first-line gefitinib (IMPRESS): a phase 3 randomised trial. Lancet Oncol 2015;16:990-998.

-96 Kim H, Yang JM, Jin Y, Jheon S, Kim K, Lee CT, Chung JH, Paik JH: MicroRNA expression profiles and clinicopathological implications in lung adenocarcinoma according to EGFR, KRAS, and ALK status. Oncotarget 2017;8:8484-8498.

97 Cheng N, Li X, Zhao C, Ren S, Chen X, Cai W, Zhao M, Zhang Y, Li J, Wang Q Zhou C: Microarray expression profile of long non-coding RNAs in EGFR-TKIs resistance of human non-small cell lung cancer. Oncol Rep 2015;33:833-839.

98 Li H, Schmid-Bindert G, Wang D, Zhao Y, Yang X, Su B, Zhou C: Blocking the PI3K/AKT and MEK/ERK signaling pathways can overcome gefitinib-resistance in non-small cell lung cancer cell lines. Adv Med Sci 2011;56:275-284.

-99 Sordella R, Bell DW, Haber DA, Settleman J: Gefitinib-sensitizing EGFR mutations in lung cancer activate anti-apoptotic pathways. Science 2004;305:1163-1167.

100 Ng KP, Hillmer AM, Chuah CT, Juan WC, Ko TK, Teo AS, Ariyaratne PN, Takahashi N, Sawada K, Fei Y, Soh S, Lee WH, Huang JW, Allen JC, Jr., Woo XY, Nagarajan N, Kumar V, Thalamuthu A, Poh WT, Ang AL, et al.: A common BIM deletion polymorphism mediates intrinsic resistance and inferior responses to tyrosine kinase inhibitors in cancer. Nat Med 2012;18:521-528.

101 Wu Y, Yu DD, Hu Y, Yan D, Chen X, Cao HX, Yu SR, Wang Z, Feng JF: Genome-wide profiling of long noncoding RNA expression patterns in the EGFR-TKI resistance of lung adenocarcinoma by microarray. Oncol Rep 2016;35:3371-3386.

102 Wang B, Jiang H, Wang L, Chen X, Wu K, Zhang S, Ma S, Xia B: Increased MIR31HG IncRNA expression increases gefitinib resistance in non-small cell lung cancer cell lines through the EGFR/PI3K/AKT signaling pathway. Oncol Lett 2017;13:3494-3500.

103 Ma P, Zhang M, Nie F, Huang Z, He J, Li W, Han L: Transcriptome analysis of EGFR tyrosine kinase inhibitors resistance associated long noncoding RNA in non-small cell lung cancer. Biomed Pharmacother 2017;87:20-26.

104 Pan H, Jiang T, Cheng N, Wang Q, Ren S, Li X, Zhao C, Zhang L, Cai W, Zhou C: Long non-coding RNA BC087858 induces non-T790M mutation acquired resistance to EGFR-TKIs by activating PI3K/AKT and MEK/ERK pathways and EMT in non-small-cell lung cancer. Oncotarget 2016;7:49948-49960.

105 Dong S, Qu X, Li W, Zhong X, Li P, Yang S, Chen X, Shao M, Zhang L: The long non-coding RNA, GAS5, enhances gefitinib-induced cell death in innate EGFR tyrosine kinase inhibitor-resistant lung adenocarcinoma cells with wide-type EGFR via downregulation of the IGF-1R expression. J Hematol Oncol 2015;8:43.

106 Cao L, Chen J, Ou B, Liu C, Zou Y, Chen Q: GAS5 knockdown reduces the chemo-sensitivity of non-small cell lung cancer (NSCLC) cell to cisplatin (DDP) through regulating miR-21/PTEN axis. Biomed Pharmacother 2017;93:570-579.

107 Wu Y, Yu DD, Hu Y, Yan DL, Chen X, Zhang HD, Cao HX, Yu SR, Wang Z, Feng JF: WITHDRAWN: The long noncoding RNA, LINC00635-001, sensitizes EGFR-TKI-resistant human lung cancer cells in vitro by inhibiting Akt activation. Biochem Biophys Res Commun 2016; DOI:10.1016/j.bbrc.2016.01.057.

108 Lin A, Hu Q, Li C, Xing Z, Ma G, Wang C, Li J, Ye Y, Yao J, Liang K, Wang S, Park PK, Marks JR, Zhou Y, Zhou J, Hung MC, Liang H, Hu Z, Shen H, Hawke DH, et al.: The LINK-A IncRNA interacts with PtdIns $(3,4,5) P 3$ to hyperactivate AKT and confer resistance to AKT inhibitors. Nat Cell Biol 2017;19:238-251. 